\title{
Aspecte clinico-evolutive în infecția cu Coxiella burnetii
}

\author{
Maria Cristina Hoară ${ }^{1}$, Simin-Aysel Florescu ${ }^{1,2}$, Sebastian Alexandru Pişcu' ${ }^{1}$ \\ Grațiela Țârdei', Petre lacob Calistru1,2 \\ ${ }^{1}$ Spitalul Clinic de Boli Infecţioase şi Tropicale „Dr. Victor Babeş“, Bucureşti, România \\ ${ }^{2}$ Clinica de Boli Infecţioase şi Tropicale „Dr. Victor Babeş“, \\ Universitatea de Medicină şi Farmacie „Carol Davila“, Bucureşti, România
}

\begin{abstract}
REZUMAT
Introducere. Coxiella burnetii este agentul etiologic al febrei Q, o zoonoză care încă ridică semne de întrebare - „Query“. Anterior clasificată drept Rickettsie, C. burnetii este o bacterie obligatoriu intracelulară înalt infecţioasă, ale cărei principale rezervoare animale sunt bovinele, ovinele şi caprinele. Transmisă în mod obişnuit prin inhalarea aerosolilor contaminaţi în timpul parturiţiei animale, febra $Q$ se poate manifesta ca boală febrilă autolimitată, pneumonie sau hepatită. Cu toate acestea, în anumite circumstanţe, există posibilitatea evoluţiei către o formă cronică, implicând predominant valvele cardiace preexistent lezate sau vasele de sânge. Diagnosticul este uzual stabilit serologic, iar Doxiciclina reprezintă cea mai frecventă alegere de antibioterapie.

Obiective. Scopul acestui studiu este de a analiza cadrul clinic şi de laborator care a condus la diagnosticul de febră $Q$ acută, respectiv cronică, regimurile de tratament aplicate şi evoluţia consecutivă în cadrul grupului de pacienţi definit mai jos.

Materiale şi metode. Lucrarea de faţă reprezintă un studiu observaţional descriptiv bazat pe un lot de 24 de pacienţi internaţi în clinica noastră în anul 2018 şi diagnosticaţi cu febră Q acută sau cronică, probabilă sau confirmată. Au fost incluşi bolnavi de ambele sexe, indiferent de vârstă, sub condiţia respectării definiţiei de caz a CDC, integrând modificările serologice în contextul clinic compatibil cu tabloul bolii.

Rezultate şi concluzii. Un cadru epidemiologic sugestiv a fost identificat în puţine cazuri. Dintre cei 24 de bolnavi cu vârste curpinse între 34 şi 80 de ani, dintre care doar două au fost femei, 22 au experimentat febră $Q$ acută, manifestată predominant ca o combinaţie de penumonie şi hepatită ( 9 cazuri, $41 \%)$. Doar două cazuri de infecţie acută au fost confirmate serologic. Acuze frecvente au fost febra (în toate situaţiile), frisoanele, cefaleea şi greaţa. Numai $28 \%$ dintre pneumoniile confirmate imagistic au fost acompaniate de tuse seacă, în timp ce doar $21 \%$ dintre hepatite au asociat icter. Biologic, leucocitoza s-a corelat mai slab cu activitatea bolii acute, în timp ce toţi pacienţii au exprimat un răspuns inflamator (prin proteina $\mathrm{C}$ reactivă) moderat-crescut. Având în vedere latenţa sosirii rezultatelor dozării anticorpilor specifici, decizia de iniţiere a tratamentului a fost bazată pe considerente clinice, antibioterapia constând în Doxiciclină, singură sau în combinaţii menite să acopere un spectru mai larg, dat fiind caracterul obişnuit nespecific al simptomelor şi suspiciunea clinică iniţial mică pentru febră Q. Evoluţia a fost favorabilă în toate cazurile. Privitor la cei doi pacienţi cu febră Q cronică, manifestată ca endocardită cu hemoculturi negative, dintre care doar una confirmată potrivit definiţiei $C D C$, ambii prezentau valvulopatii constituite premergător, în absenţa unui istoric de infecţie acută cu C. burnetii. În primul caz, sub antibioterapie empirică pentru El (Ceftriaxonă şi Vancomicină), a survenit insuficienţa cardiacă acută şi s-a impus protezarea valvulară chirurgicală, urmând ca titrul înalt de lgG fază I ce aducea confirmarea diagnostică să fie ulterior obiectivat. Celui de-al doilea bolnav i-a fost administrată şi Doxiciclina în combinaţie terapeutică, evoluând favorabil pe parcursul internării.
\end{abstract}

Cuvinte cheie: Coxiella burnetii, febră Q, Doxiciclină

\section{INTRODUCERE}

Coxiella burnetii reprezintă agentul etiologic al febrei Q, boală a cărei denumire aminteşte de semnul de întrebare („Query“) ridicat de Derrick în anul 1935, în urma observării unui sindrom febril izbucnit în focar în rândul unor muncitori la un abator din Brisbane, fără o cauză explicabilă la acel moment. Ulterior, două echipe de cercetători au identificat agentul cauzal aproape simultan, iniţial clasificat drept o Rickettsie: Burnet şi Freeman, în 
Australia, respectiv Davis şi Cox, în SUA. Actual, patogenul intracelular a fost reclasificat ca gamaproteobacterie, fiind înrudit mai mult cu Legionella spp. Morfologic, C. burnetii are caracterele unui cocobacil pleomorf, formator de spori foarte rezistenţi în mediu, cu un perete celular cu structură Gram-negativă. Particulară este variaţia de fază antigenică pe care o parcurge, prin intermediul schimbării compoziţiei lipopolizaharidului de suprafaţă, fapt cu implicaţie în încadrarea răspunsului serologic în forma acută, respectiv cronică de boală $(3,4,5)$.

Distribuţia geografică a $C$. burnetii cuprinde aproape întreg globul, excepţie făcând Arctica, Antarctica şi Noua Zeelandă. Având în vedere atât modalitatea principală de transmitere a infecţiei, şi anume prin inhalarea de aerosoli contaminaţi cu precădere în timpul parturiţiei animale (patogenul concentrându-se intens la nivelul placentei), cât şi doza infectantă mică necesară contractării bolii, se poate discuta despre un potenţial agent de bioterorism. Principalele rezervoare animale sunt reprezentate de ovine, caprine şi bovine, fapt ce denotă caracterul ocupaţional al febrei $Q$, fiind vorba despre medici veterinari, fermieri şi lucrători la abator, ce intră în contact direct cu animalele infectate, adesea asimptomatice. Nu trebuie uitate însă şi alte specii animale, respectiv peştii, păsările, porcinele, câinii, pisicile, dar şi vieţuitoarele sălbatice, toate acestea fiind la rândul lor infectate prin muşcătura sau contaminarea cu dejectele unor căpuşe sau alte artropode, la nivelul cărora bacteria persistă $(3,4,5)$.

În ciuda celor prezentate mai sus, adesea nu se poate stabili o conexiune epidemiologică între un caz suspectat a fi febră Q şi sursa infectantă, întrucât boala se poate transmite şi indirect, prin paie sau praf contaminate, multiple epidemii fiind documentate la locuitorii aflaţi la câţiva kilometri de o fermă sau de-a lungul unui drum frecventat de transporturi de animale. În plus, acestea din urmă elimină microorganismul şi prin urină, fecale şi lapte, ceea ce explică o a doua posibilitate de contractare a infecţiei, şi anume ingestia de produse lactate nepasteurizate. Alte modalităţi de transmitere mai rar citate presupun pătrunderea cutanată a bacteriei prin strivirea unei căpuşe infectate, transfuziile de sânge, contactul sexual, pasajul maternofetal, contactul intrafamilial şi participarea la autopsia/asistenţa la naştere a unor persoane infectate $(4,5)$.
Prima fază a bolii, febra Q acută, apare consecutiv unei perioade de incubaţie ce variază de la 1 la 39 de zile - în funcţie de doza infectantă, cu o medie de 20 de zile. Raportat la gazdă, tulpina bacteriană şi doza infectantă, infecţia poate fi atât asimptomatică, cu precădere în rândul copiilor şi al femeilor, mai ales al celor gravide, hormonii steroizi fiind incriminaţi în acest determinism, cât şi clinic manifestă, cea mai comună formă dezvoltată fiind boala febrilă autolimitată (sindrom pseudogripal), cu o durată de 1-3 săptămâni, particularităţile sale constând în debutul brusc cu febră înaltă, frisoane, fatigabilitate, mialgii, greaţă, vărsături, diaree şi o cefalee retroorbitală adesea severă ce poate fi însoţită de fotofobie. Acest din urmă fapt conduce uneori la realizarea puncţiei lombare, literatura citând prezenţa în rare situaţii a $C$. burnetii în $\operatorname{LCR}(4,11)$.

O altă formă clinică de boală o reprezintă pneumonia, exprimată prin tabloul antemenţionat, la care se adaugă, rareori, tusea seacă şi durerea cu caracter pleuritic, întrunind criteriile pneumoniei atipice. Radiologic, aspectele imagistice pot varia de la o opacitate adesea cu baza la pleură, greu de diferenţiat de un focar de condensare cu altă etiologie bacteriană, opacităţi multifocale bilaterale asociate în literatură cu expunerea la produsele biologice rezultate în urma parturiţiei pisicilor domestice, respectiv desen reticulo-nodular interstiţial accentuat. $\mathrm{O}$ a treia formă clinică de boală acută poate fi hepatita, uzual anicterică, acompaniată biologic de o hepatocitoliză adesea minimă-moderată (creştere a nivelului transaminazelor de 2-3 ori peste valoarea superioară a normalului), dar care poate ajunge la valorile întâlnite în hepatitele virale acute; hepatosplenomegalia este inconstantă, iar marca histopatologică este reprezentată de granuloamele „doughnut like“. Printre alte expresii clinice ale infecţiei acute se numără endocardita acută, pericardita, meningita aseptică etc. Alte caracteristici paraclinice ale acestei faze sunt identificarea unui număr frecvent normal de leucocite (doar un sfert până la o treime dintre cazuri dezvoltă leucocitoză), sindromul inflamator cuantificat prin proteina $\mathrm{C}$ reactivă ce se corelează cu activitatea bolii şi variaţia numărului de trombocite - aproximativ un sfert dintre bolnavi au trombocitopenie, în timp ce în convalescenţă poate să apară trombocitoza $(4,5,11)$. 
În lipsa antibioterapiei corespunzătoare, anumite categorii de persoane se află la risc de cronicizare a febrei $\mathrm{Q}$, indiferent de forma manifestă sau lipsită de simptome a fazei acute. Astfel, imunodeprimaţii, gravidele, cei diagnosticaţi cu valvulopatii sau anevrisme vasculare, purtătorii de proteze valvulare, vasculare sau articulare pot dezvolta febră Q cronică, manifestată cel mai frecvent prin endocardită, infecție vasculară sau articulară, în zonele anterior afectate sau protezate. În aceste situaţii, particulară este absenţa uzuală a febrei. Referitor la EI, vegetaţiile dezvoltate reflectă multiplicarea intracelulară a microorganismului, având dimensiuni mici şi aspect nodular, fiind greu vizualizabile la ecocardiografia transtoracică, iar hemoculturile sunt negative. În până la o treime dintre cazuri, poate surveni embolia arterială. În plus, hepatosplenomegalia însoţeşte frecvent tabloul clinic, iar uneori poate apărea un rash purpuric. Biologic, faza cronică înregistrează un sindrom inflamator, hipergamaglobulinemie şi anemie intrainfecţioasă $(4,5)$.

Uzual, diagnosticul celor două forme de boală se stabileşte prin corelarea suspiciunii clinice cu răspunsul serologic specific, cuantificat prin imunofluorescenţă. Există două grupe de anticorpi - de fază I, asociaţi infecţiei cronice, respectiv de fază II, corespunzând infecţiei acute. Ambele grupe conţin anticorpi de tip IgM, respectiv IgG. Cu toate acestea, se pot practica şi teste moleculare - PCR, izolarea $C$. burnetii din culturi celulare sau imagistică performantă - CT, IRM, 18F-FDG-PET/CT $(4,5)$. Clasic, se consideră că seroconversia în febra Q acută apare la 7-15 zile de la debutul simptomatologiei, 90\% dintre pacienţi dezvoltând anticorpi până în săptămâna a treia, crescând până la un peak seric în săptămânile 4-8, scăzând ulterior gradual pe parcursul unui an (11). Cu toate acestea, un studiu serologic recent subliniază variabilitatea interindividuală marcată a răspunsului imun. $\operatorname{IgG}$ fază II ar fi de obicei primul anticorp sintetizat, însă oricare dintre cei patru pot fi detectaţi încă de la începutul bolii sau dimpotrivă, începând chiar cu peste 150 de zile de la debut (6). Drept urmare, indicaţia actuală de iniţiere a antibioterapiei este dată de suspiciunea clinică, având în vedere că serologia poate fi negativă în primele zile ale bolii. În plus, se pare că administrarea promptă a medicaţiei antibiotice nu împiedică seroconversia şi nu afectează creşte- rea titrului de anticorpi, fapt ce permite diagnosticul retroactiv (7).

De altfel, febra Q face subiectul unor opinii ştiinţifice contradictorii în ceea ce priveşte criteriile serologice de diagnostic, raportat la titrurile de imunoglobuline de la care se poate afirma acesta. Această lucrare a fost ghidată de cea mai recentă propunere a CDC pentru definiţia de caz (2009) a infecţiei cu C. burnetii (8). Drept urmare, în ceea ce priveşte faza acută a bolii, criteriile de laborator pot fie să confirme diagnosticul, fie doar să îl susţină. În prima situaţie, creşterea de 4 ori a titrului IgG fază II prin IFA pe probe de ser recoltate la 3-6 săptămâni distanţă, în convalescenţă (ideal, prima probă este recoltată în prima săptămână de la debut şi probele sunt analizate simultan ulterior folosind acelaşi kit de lucru), identificarea materialului genetic bacterian prin PCR, izolarea patogenului din culturi celulare sau utilizarea tehnicilor imunohistochimice de detecţie confirmă un caz de febră Q acută, în contextul existenţei unui tablou clinic sugestiv sau al unei conexiuni epidemiologice între persoana în cauză şi un alt caz confirmat în laborator. Pe de altă parte, o singură determinare de IgG fază II în titru de cel puţin 1:128 prin IFA susţine diagnosticul, definind cazul probabil de febră Q acută, în prezenţa simptomatologiei descrise. Această situaţie este cel mai frecvent întâlnită, parţial din cauza lipsei prezentării la medic a bolnavilor din primele zile de la debut, dar şi din cauza suspiciunii clinice iniţiale mici, care duc la ratarea momentului ideal de recoltare a primei probe de ser, în vederea testării de seruri pereche. De asemenea, alte metode de detecţie a anticorpilor ce susţin diagnosticul de infecţie acută sunt ELISA şi aglutinarea latex. $\mathrm{O}$ menţiune importantă este reprezentată de recomandarea CDC de a nu utiliza anticorpii de tip IgM fază II în demersul diagnostic al fazei acute, având în vedere persistenţa lor îndelungată şi riscul mai înalt de cross-reactivitate cu imunoglobuline specifice altor microorganisme, precum Legionella spp. şi Bartonella spp. $(7,8)$.

Diagnosticul etapei cronice de boală este supus şi mai mult dezbaterii. Conform definiţiei de caz a CDC din 2009, febra Q cronică se confirmă în faţa unei endocardite cu hemoculturi negative, suspiciunii unei infecţii de anevrism sau proteză vasculară, respectiv a unei osteoartrite sau osteomielite, atunci când titrul de IgG fază I este de cel puţin 
1:800 prin IFA (de altfel, şi criteriu major conform setului de criterii modificate Duke) sau agentul patogen este identificat prin PCR, IHC sau culturi celulare. Clasic, se consideră că, deşi titrul IgG fază II rămâne crescut şi în această etapă, anticorpii de primă fază exced. Un studiu recent consideră această condiţie drept o suprasimplificare, având în vedere variabilitatea înaltă a răspunsului serologic între indivizi (2). Un caz probabil de infecţie cronică presupune un titru de cel puţin 1:128 al IgG fază I, dar mai mic decât 1:800, CDC fiind singurul set de criterii ce atribuie titruri sub 1:800 unui caz potenţial. Propuneri alternative aparţin unor consensuri de experţi - Raoult et al. (2012), respectiv "Dutch consensus", a căror dezvoltare nu face obiectul lucrării de faţă $(4,8)$.

Referitor la tratamentul infecţiei cu C. burnetii, în prima etapă eficace este Doxiciclina per os în doză de 100 mg x 2/zi, timp de două săptămâni, având ca alternative macrolidele, fluoroqinolonele si cotrimoxazolul. Important de reţinut este faptul că în cazul pacienţilor purtători de leziuni sau proteze valvulare, se impune profilaxia afectării cronice cu dubla terapie Doxiciclină (în aceeaşi doză) şi Hidroxiclorochină 200 mg x 3/zi, timp de 1 an. De altfel, unii autori sugerează efectuarea unei ecocardiografii transesofagiene în toate cazurile de febră Q acută depistate, în vederea descoperirii unor valvulopatii predispozante pentru EI şi aplicării tratamentului profilactic. Efectul Hidroxiclorochinei nu este unul antibacterian, ci de alcalinizare a mediului acid al fagolizozomului în care se multiplică $C$. burnetii, potenţând astfel acţiunea antibioticului. În faza cronică, pacienţilor li se aplică biterapia mai sus menţionată, însă continuată timp de minim un an si jumătate în EI pe valve native, infecţia vasculară sau osteo-articulară şi până la 2 ani în EI survenită pe proteză valvulară $(4,5,11)$.

\section{OBIECTIVELE LUCRĂRII}

Lucrarea de faţă îşi propune analiza comparativă atât interindividuală, cât şi raportată la datele din literatură a contextelor epidemiologice, clinice şi de laborator care au condus la formularea diagnosticului de febră Q acută sau cronică, regimurilor de tratament aplicate, respectiv evoluţiei ulterioare într-un lot de pacienţi internaţi în cadrul Spitalului Clinic de Boli Infecţioase şi Tropicale „Dr. Victor Babeş““ din Bucureşti în anul 2018.

\section{MATERIALE ŞI METODE}

Tipul studiului realizat este unul observaţional descriptiv. Lotul de studiu cuprinde 24 de pacienţi de ambele sexe, cu vârste cuprinse între 34 şi 80 de ani, internaţi în perioada ianuarie-decembrie 2018 în secţiile de boli infecţioase ale spitalului nostru. Selecţia cazurilor a fost bazată pe un set de criterii, după cum urmează:

a. Criterii de includere:

- internare în formă continuă în cursul anului 2018;

- diagnostic de febră Q stabilit în cursul anului 2018;

- diagnostic stabilit conform definiţiei de caz confirmat sau probabil de febră Q acută, respectiv cronică (CDC 2009).

b. Criterii de excludere:

- internare de zi, având diagnostic stabilit anterior anului 2018 (pacienti veniţi la reevaluare);

- diagnostic ce nu respectă definiţia de caz a CDC - cazuri cu serologii compatibile, dar clinică sugestivă pentru un alt diagnostic mai probabil - posibile cross-reactivităţi sau cazuri sugestive clinic pentru febră Q, dar serologii insuficiente pentru a susţine diagnosticul.

\section{REZULTATE ŞI DISCUȚII}

Faţă de alte ţări europene, conform unui raport ECDC elaborat recent, pentru anul 2016, România se situa în grupa secundă ca număr mediu al cazurilor confirmate (50), fiind devansată de state precum Franţa, Spania şi Germania (9). În anul 2017, ECDC centraliza 48 de cazuri provenind din ţara noastră, în creştere faţă de anii precedenţi (10). Lotul de 24 de pacienţi din studiul de faţă concordă astfel cu datele prezentate, având în vedere că nu intră în discuţie cazurile identificate în alte clinici de profil din ţară în anul 2018.

Revenind la lucrarea de faţă, privind contextul epidemiologic, din Figura 1 se observă că majoritatea subiecţilor au fost bărbaţi (22 de cazuri, respectiv 91,6\%), ceea ce nu se corelează neapărat cu un tropism al C. burnetii pentru sexul masculin, ci mai degrabă cu prevalenţa crescută a infecţiei asimptomatice în rândul femeilor, precum am 


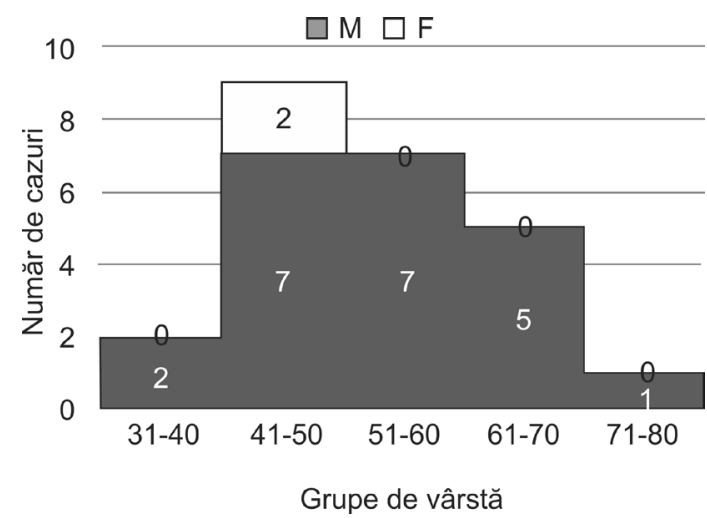

FIGURA 1. Distribuția în funcție de vârstă şi sex a cazurilor din lotul studiat

expus în prima parte a lucrării. Segmentul de vârstă cel mai afectat a fost între 41 şi 50 de ani (9 cazuri), urmat îndeaproape de intervalul 51-60 ani (7 cazuri), nefiind înregistrate cazuri în rândul copiilor (Figura 1), care sunt frecvent asimptomatici, fapt de asemenea reiterat mai sus. În funcţie de mediul de provenienţă al pacienţilor, 58\% dintre aceştia au fost din mediul urban, constatare uşor surprinzătoare, având în vedere lipsa contactului uzual cu animalele ce constituie rezervorul principal al patogenului, însă, pe de altă parte, nu trebuie uitate posesia animalelor de companie ce pot transmite boala, posibilitatea de contractare pe cale orală prin consumul de produse lactate de la producători locali şi caracterul ubicuitar al C. burnetii, ce poate fi purtată la distanţe mari de curenţii de aer.

La numai 7 pacienţi a fost documentată sursa posibilă de infectare: posesia de caprine, ovine, bovine într-un singur caz, posesia de animale de companie într-un altul, prezenţa altor animale de curte în gospodărie (4 situaţii) şi, nu în ultimul rând, un caz de consum de brânzeturi comercializate de către un cioban într-o regiune rurală, cu aproximativ 2 săptămâni anterior debutului simptomatologiei. În schimb, nu a fost documentat niciun caz de expunere profesională.

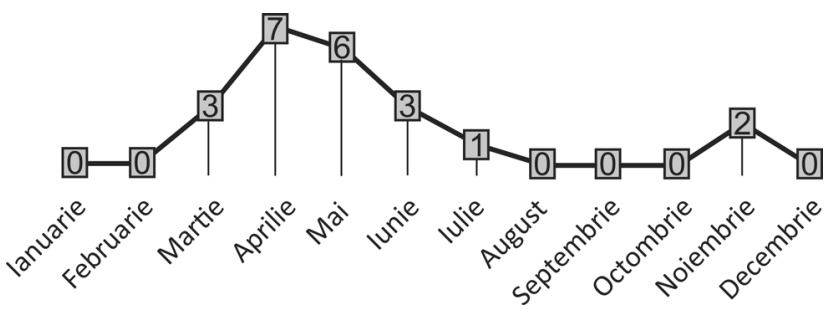

FIGURA 2. Distribuția sezonieră a celor 22 de cazuri de febră $Q$ acută
Urmărind distribuţia sezonieră a cazurilor de febră Q acută, s-a remarcat o predominanţă netă a acestora (20 de indivizi) în timpul primăverii şi la începutul verii - lunile martie-iunie (Figura 2), constatare în concordanţă cu date grafice ale ECDC pentru perioada 2013-2017, care relevă un pattern anual cu vârfuri ale numărului de cazuri în lunile aprilie-mai (10).

Referitor la cauzele de imunosupresie identificate la lotul studiat (la 11 pacienţi), acestea au constat majoritar în alcoolism şi diabet zaharat. Aspectul imunodepresiei contează, precum în majoritatea bolilor infecţioase, şi în febra $Q$, atât prin prisma riscului crescut de achiziţie a infecţiei şi a caracterului mai frecvent simptomatic al acesteia, cât mai ales din cauza predispunerii la cronicizare.

Trecând la contextul clinic, lotul a fost împărţit în două grupe în funcţie de faza bolii, fiind vorba despre 22 de indivizi cu febră Q acută, respectiv de doar doi cu formă cronică, ambii dezvoltând endocardită infecţioasă cu hemoculturi negative. În prima categorie de pacienţi, în numai două situaţii boala a fost confirmată serologic, restul reprezentând cazuri probabile. Această constatare nu este deloc surprinzătoare, având în vedere datele prezentate anterior în cadrul discuţiei definiţiei de caz a CDC, dar se poate datora în parte unei limite a studiului, precum dozarea anticorpilor de tip $\operatorname{IgG}$ fază II din serul pereche în ambulator, ulterior externării, datele nefiind disponibile prin prisma caracterului retrospectiv al acestui studiu. Raportat la cazurile de EI, doar unul dintre ele a fost confirmat în laborator.

Privitor la formele clinice de infecţie acută identificate, precum se arată mai jos (Figura 3), a predominat concomitenţa pneumonie-hepatită ( 9 cazuri, reprezentând $41 \%$ ), urmată de penumonie, respectiv hepatită (considerată de la un nivel al creşterii TGP de cel puţin 2 ori peste valoarea superioară a normalului) ca unică determinare clinică, fiecare reprezentând un procent de $18 \%$ dintre cazuri; alte 18 procente au corespuns bolii febrile autolimitate. $\mathrm{Nu}$ în ultimul rând, în cazul unui bărbat a fost regăsită şi o formă clinică mai rar întâlnită - pericardita acută.

Manifestările clinice documentate în cadrul afecţiunii acute au fost majoritar de ordin general (febră, frisoane, mialgii, greaţă), 7 pacienţi experimentând cefalee, dar lipsită de caracterul retroorbi- 


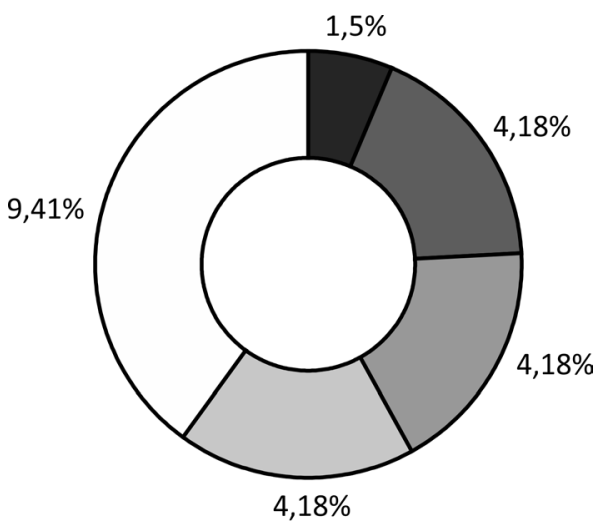

Pericardită, pneumonie și hepatită

Boală febrilă autolimitată

Pneumonie

$\square$ Hepatită

$\square$ Pneumonie și Hepatită

FIGURA 3. Forme clinice de febră $Q$ acută identificate la lotul studiat

tar adesea descris şi neînsoţită de fotofobie. În plus, dintre cei 14 subiecţi care au dezvoltat pneumonie interstiţială (accentuarea desenului interstiţial pulmonar fiind singura modificare radiologică întâlnită), doar 4 au manifestat tuse seacă $(28 \%)$, iar în rândul celor 14 cazuri de hepatită, doar 3 au fost acompaniate de subicter scleral (21\%), rezultate ce confirmă datele din literatură. De asemenea, 78\% dintre hepatite au determinat hepatosplenomegalie decelată clinic sau ecografic.

Din punct de vedere paraclinic, în mai puţin de jumătate dintre cazurile de febră $\mathrm{Q}$ acută a fost remarcată leucocitoza (45\%), fapt ce denotă corelaţia ei mai slabă cu această infecţie bacteriană. $86 \%$ dintre pacienţi au dezvoltat cel puţin un grad minim de hepatocitoliză (considerată începând cu orice creştere peste valoarea superioară a normalului a TGP), iar la 31\% dintre aceştia s-a identificat trombocitopenie, date similare celor citate în prima parte a expunerii (Figura 4). În ciuda numărului de leucocite frecvent normal, clinicianul este însă ghidat către o sursă bacteriană de infecţie prin intermediul valorii proteinei $\mathrm{C}$ reactive, ridicată în toate cazurile de febră Q acută incluse în lot, de la valori moderate de sub $5 \mathrm{mg} / \mathrm{dl}$ până la o maximă de 40 mg/dl, după cum se poate observa mai jos, în Figura 5. Pe de altă parte, un alt marker inflamator util - procalcitonina, a atins un nivel semnificativ crescut $(>2 \mathrm{ng} / \mathrm{ml})$ în 7 dintre cele 10 situaţii în care a fost dozată, fără ca un alt focar infecţios bacterian să fie obiectivat, rezultat contrar informaţiilor oferite de studiile publicate până în prezent. Mai mult decât atât, în cazul bărbatului infectat pe cale orală prin consum de brânzeturi nepasteurizate, ce a manifestat pneumonie şi hepatită, procalcitonina a ascensionat până la o valoare de aproape $22 \mathrm{ng} / \mathrm{ml}$, având semnificaţie de sepsis. Evoluţia clinică a fost însă favorabilă.

În continuare, vom explicita modul în care dinamica anticorpilor specifici a dus la formularea diagnosticului în cele două cazuri de febră Q acută confirmată, urmărind Figurile 6 şi 7 de mai jos. Astfel, în ambele situaţii, s-a putut observa creşterea de mai mult de 4 ori a titrurilor de IgG fază II între perechile de seruri. În al doilea caz, deşi proba iniţială fusese recoltată relativ tardiv (la 20 de zile de
—IP $\downarrow$
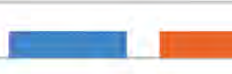

a Hiperbilirubinemie

Hiperbilirubinemie

$$
\begin{aligned}
& \text { veTrombocitoză } \\
& \text { n Leucocitoză }
\end{aligned}
$$
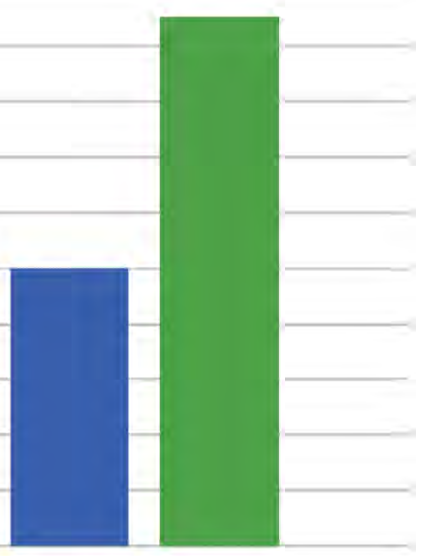

뜸 Trombocitopenie

—Citoliză hepatică
FIGURA 4. Modificări de laborator în cadrul grupului de pacienți cu febră $Q$ acută 


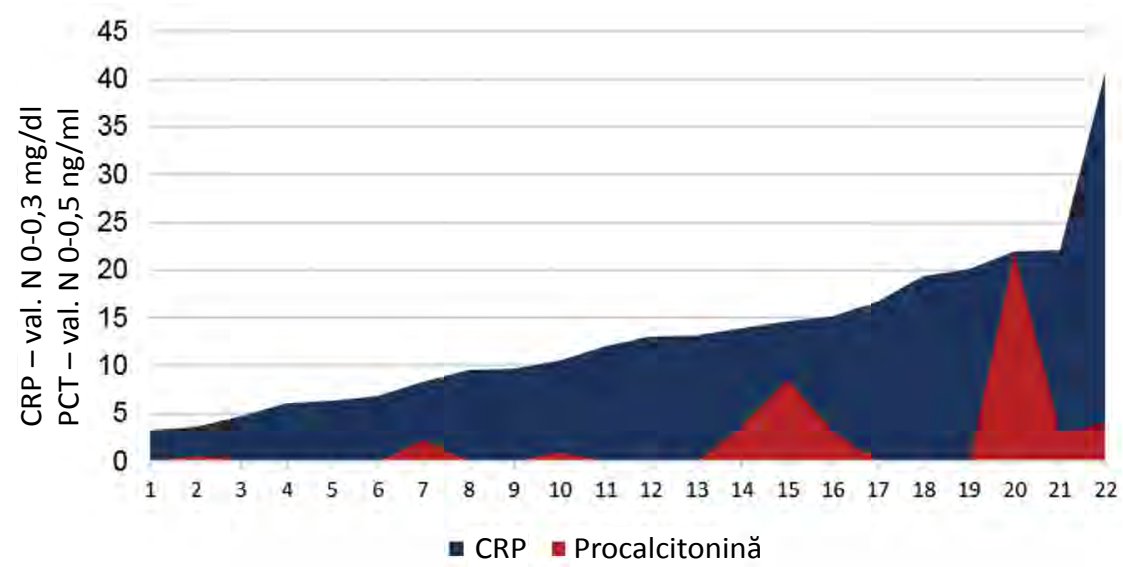

FIGURA 5. Modificări inflamatorii în cadrul grupului de pacienți cu febră Q acută

la primele simptome), al cărei titru de anticorpi era semnificativ crescut la acel moment (IgG fază II = 1:1.024), confirmarea serologică a fost totuşi obţinută prin atingerea ulterioară a unei valori impresionante - 1:132.000, fapt ce îndeplineşte cerinţele definiţiei de caz. Tot aici, particulară este elevarea importantă a titrului IgG fază I la a treia determinare serologică, constatare ce justifică urmărirea atentă a bolnavului, mai ales prin prisma preexistenţei unei valvulopatii aortice, acesta având risc ridicat de cronicizare a infecţiei. Determinări serologice în dinamică au fost lucrate şi în alte 3 cazuri, însă întârzierea primei recoltări (la 10,15, respectiv 18 zile de la primele simptome) a dus la depăşirea momentului titrului de vârf, fapt ce a ratat obiectivarea creşterii lui în timp. Prin comparaţie cu al doilea caz confirmat expus mai sus, se poate trage concluzia variaţiei interindividuale mari a duratei dintre debutul simptomatologiei şi seroconversie, respectiv atingerea peak-ului seric al IgG fază II. Alte 17 cazuri probabile de infecţie acută au fost depistate ca urmare a unei singure determinări de anticorpi, dezvoltând titruri de la valoarea minimă acceptată ca diagnostică (1:128) până la un nivel maxim de $1: 16.000$.

O observaţie interesantă a fost aceea că în 4 cazuri de febră Q acută au fost identificaţi anticorpi tip IgM specifici virusului Epstein-Barr, respectiv bacteriilor intracelulare Chlamydia şi Mycoplasma, serologii recoltate ca urmare ca gradului înalt de suspiciune în contextul unui tablou clinic relativ nespecific. Deşi acest lucru ar putea releva, teoretic, infecţii concomitente, mai probabilă este varianta cross-reactivităţii, citată în literatură (1). Drept urmare, clinicianul trebuie cunoască acest fapt şi să judece cazul în consecinţă. Deşi impactul asupra

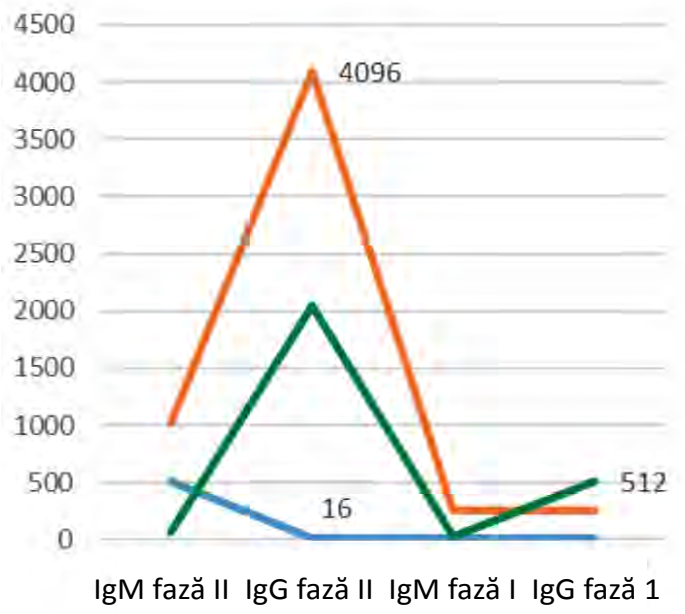

$=1-2=3$
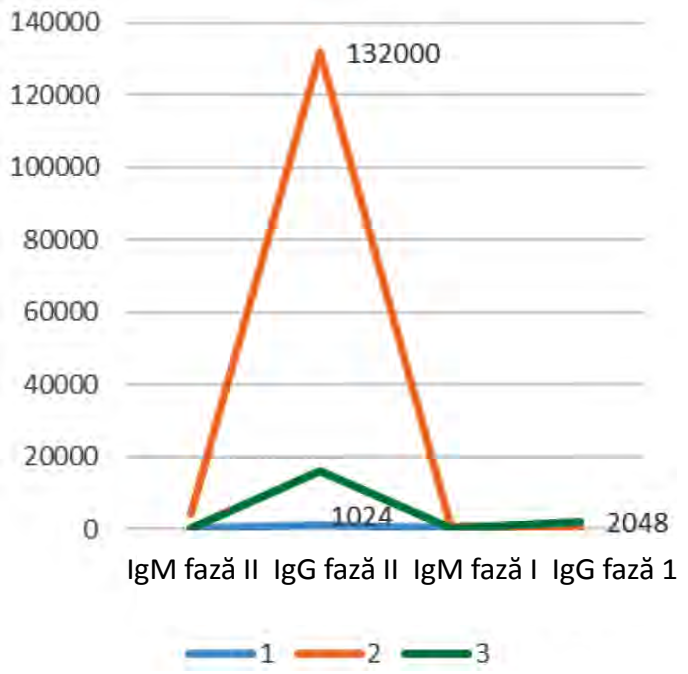

FIGURILE 6 şi 7. Dinamica anticorpilor specifici în cazurile confirmate serologic de febră Q acută 
terapiei iniţiale nu este semnificativ în cazul unei piste diagnostice greşite, febra Q poate croniciza în rândul anumitor categorii de risc, având un impact patogenic potenţial crescut în timp în lipsa recunoaşterii bolii, a unui follow-up atent şi a profilaxiei medicamentoase.

Luând în discuţie contextul terapeutic, toţi pacienţii cu formă acută au beneficiat de recomandarea standard, şi anume Doxiciclină în doză de 100 mg x 2/zi, per os, însă în numai 4 cazuri (18\%) aceasta a fost singulară, fiind mai adesea introdusă în combinaţii terapeutice. Decizia administrării altor clase antibiotice poate fi explicată prin gradul mic de suspiciune pentru infecţia cu $C$. burnetii la momentul internării şi considerarea unor alte etiologii ca fiind mai probabile, Doxiciclina fiind de multe ori adăugată ulterior, sub aspectul parcursului nefavorabil. În plus, serologiile se pozitivează tardiv, susţinând retroactiv diagnosticul, frecvent ulterior externării bolnavului. $\mathrm{Cu}$ toate acestea, clinica plasată în context epidemiologic ce sugerează boala în cauză dictează iniţierea tratamentului cu Doxiciclină. Durata folosirii acesteia a variat larg între 7 şi 39 de zile, dar reamintim că în mod ideal, administrarea în faza acută a febrei Q este de două săptămâni. Evoluţia clinică a fost unanim favorabilă.

Ajungând la cele două cazuri de febră $\mathbf{Q}$ cronică, manifestate prin EI cu hemoculturi negative, unul confirmat printr-un titru de $\operatorname{IgG}$ fază I > 1:16.000, cel de-al doilea având un rezultat serologic ce a susţinut doar diagnosticul (1:512), reiterăm riscul de cronicizare adus de preexistenţa unor valvulopatii cardiace şi posibilitatea de apariţie a acestei forme în absenţa documentării febrei Q acute, ce poate evolua asimptomatic. În speţă, ambii pacienţi, de sex masculin, prezentau valvulopatii aortice şi nu aveau un istoric de boală acută. Drept urmare, nu le-a fost recomandată profilaxia cu Doxiciclină şi Hidroxiclorochină. Important de menţionat este că bărbatul diagnosticat cu EI probabilă experimentase cu două luni anterior pneumonie bazală stângă şi hepatocitoliză neînsoţite de leucocitoză (documentate), posibil episodul acut de boală, dar neinterpretat şi tratat ca atare.

Obiectivarea imagistică a vegetaţiilor pe valva aortică nativă a fost făcută atât prin ecocardiografie transtoracică, dar şi prin cea transesofagiană, ambele leziuni asociind abcese perianulare. Primul bărbat, afebril (cum adesea se citează în febra Q cronică), a experimentat insuficienţă cardiacă acută, complicaţie a EI, având aşadar indicaţie de protezare valvulară. În urma transferului în secţia de chirurgie cardiacă, a fost pierdut din evidenţă, rezultatele serologice survenind ulterior şi confirmând retroactiv diagnosticul. Drept urmare, pe parcursul scurtei internări în clinica noastră, a primit exclusiv biterapia empirică pentru EI (Ceftriaxonă şi Vancomicină, 7 zile). Celui de-al doilea pacient, după o scurtă cură empirică de 4 zile, i-a fost instaurat tratamentul cu Doxicilină timp de 11 zile, cu recomandare la externare de continuare a acesteia în monoterapie până la ridicarea rezultatului serologiei. $\mathrm{Cu}$ toate acestea, şi acesta a fost pierdut din evidenţă, iar cuantificarea rezultatelor pe termen lung devine imposibilă.

\section{CONCLUZII}

1. Febra Q este o boală din ce în ce mai frecvent raportată atât în Europa, cât şi în ţara noastră, cu un impact potenţial nefavorabil în eventualitatea cronicizării;

2. Febra Q reprezintă mai frecvent apanajul bărbaţilor de vârstă adultă, o anamneză atentă fiind necesară identificării unui eventual context epidemiologic;

3. Forma acută a bolii are caracter sezonier, fiind întâlnită cu precădere în lunile martie-iulie;

4. În clinica noastră, cele mai întâlnite forme clinice de boală acută au fost pneumonia interstiţială şi hepatita, singure sau concomitent, cu predominanţa simptomelor generale în detrimentul celor locale; drept urmare, diagnosticul clinic de febră Q acută este adesea dificil, prin prisma manifestărilor majoritar nespecifice;

5. Modificările paraclinice acute implică uzual un număr normal de leucocite, sindrom de hepatocitoliză minim-moderat, sindrom inflamator moderat-sever şi, ocazional, trombocitopenie, particularităţi ce pot orienta suplimentar clinicianul;

6. Atât în forma acută, cât şi în cea cronică, diagnosticul este predominant de ordin serologic, dar trebuie analizat cu prudenţă, în contextul posibilelor cross-reactivităţi;

7. Tratamentul antibiotic de elecţie este reprezentat de Doxiciclină pe termen scurt în boala acută, 
respectiv biterapia Doxiciclină - Hidroxiclorochină, pe termen lung, în cazul febrei Q cronice;

8. Profilaxia prin biterapie timp de un an este importantă în cazul pacienţilor cu leziuni cardiace valvulare ce experimentează febră Q acută;

9. Evoluţia clinică în forma acută este uzual favo-

\section{BIBLIOGRAFIE}

1. Chung-Hsu L et al. High seroprevalence of Mycoplasma pneumoniae IgM in acute $Q$ fever by Enzyme-Linked Immunosorbent Assay. PLoS, 8(10): e77640, 2013;

2. Miller $\mathrm{H}$ et al. Trends in $\mathrm{Q}$ fever serologic testing by immunofluorescence from four large reference laboratories in the United States, 2012-2016. Scientific Reports, 8(1): 16670, 2018;

3. Million M, Raoult D. Q fever. In: Hunter's Tropical Medicine and Emerging Infectious Disease, 9th edition. Editors: Magill AJ, Solomon T, Hill DR, Ryan ET. Ed. Saunders, Elsevier, 2012. p. 558;

4. Raoult D, Marrie TJ. Coxiella burnetii ( $Q$ fever). In: Mandell, Douglas and Bennett's Principles and Practice of Infectious Diseases 8th edition. Editors: Bennett JE, Dolin R, Blaser M. Ed. Saunders, Elsevier, Philadelphia, 2015; pp. 2208-2216;

5. Walker DH, Dumler S, Marrie TJ. Rickettsial diseases. In: Harrison's Infectious Diseases, 3rd edition. Editors: Kasper D, Fauci A. Ed. McGraw Hill, USA, 2017; pp. 696-698; rabilă, dar grevată frecvent de morbiditate cardiovasculară în cazul persoanelor cu factori de risc pentru dezvoltarea formei cronice.

Conflict of interest: none declared Financial support: none declared
6. Wielders $\mathrm{CCH}$ et al. Kinetics of antibody response to Coxiella burnetii infection ( $Q$ fever): Estimation of the seroresponse onset from antibody levels. Epidemics, 13: 37-43, 2015;

7. www.cdc.gov - Morbidity and Mortality Weekly Report - Diagnosis and Management of Q Fever — United States, 2013: Recommendations from $C D C$ and the $Q$ Fever Working Group;

8. www.cdc.gov $-Q$ fever - Case definition;

9. www.ecdc.europa.eu - Surveillance Report - Annual Epidemiological Report for 2016, Q fever - Stockholm, January 2019;

10. www.efsa.europa.eu - The European Union summary report on trends and sources of zoonoses, zoonotic agents and food-borne outbreaks in 2017 - November 2018;

11. www.uptodate.ro - Didier R., Clinical manifestations and diagnosis of $Q$ fever. 